\title{
Gut microbiota impacts bone via B.vulgatus-valeric acid-related pathways
}

Xu Lin 2, 1, \#, Hong-Mei Xiao 3, \#, *, Hui-Min Liu ${ }^{3}$, Wan-Qiang Lv ${ }^{3}$, Jonathan Greenbaum ${ }^{1}$, Si-Jie Yuan ${ }^{2}$, Rui Gong ${ }^{2}$, Qiang Zhang ${ }^{1}$, Yuan-Cheng Chen ${ }^{2}$, Cheng Peng ${ }^{2}$, Xue-Juan $\mathrm{Xu}{ }^{2}$, Dao-Yan Pan ${ }^{2}$, Zhi Chen ${ }^{2}$, Zhang-Fang Li ${ }^{2}$, Rou Zhou ${ }^{2}$, Xia-Fang Wang ${ }^{2}$, Jun-Min Lu ${ }^{2}$, Zeng-Xin Ao ${ }^{2}$, Yu-Qian Song ${ }^{2}$, Yin-Hua Zhang ${ }^{2}$, Kuan-Jui Su ${ }^{1}$, Xiang-He Meng ${ }^{1}$, Chang-Li Ge ${ }^{4}$, Feng-Ye Lv ${ }^{4}$, Xing-Ming Shi ${ }^{5}$, Qi Zhao ${ }^{6}$, Bo-Yi Guo ${ }^{7}$, Neng-Jun Yi ${ }^{7}$, Hui Shen ${ }^{1}$, Christopher J. Papasian ${ }^{8}$, Jie Shen ${ }^{2}$, 9, *, Hong-Wen Deng 1,3, *

1 Tulane Center for Bioinformatics and Genomics, School of Public Health and Tropical Medicine, Tulane University, New Orleans, LA 70112, USA

2 Department of Endocrinology and Metabolism, The Third Affiliated Hospital of Southern Medical University, Guangzhou 510630, China

3 Center of System Biology, Data Information and Reproductive Health, School of Basic Medical Science, Central South University, Changsha 410008, China

4 LC-Bio Technologies (Hangzhou) CO., LTD., Hangzhou 310018, China

5 Departments of Neuroscience \& Regenerative Medicine and Orthopaedic Surgery, Medical College of Georgia, Augusta University, Augusta, GA, USA

6 Department of Preventive Medicine, College of Medicine, University of Tennessee Health Science Center, Memphis, TN 38163, USA

7 Department of Biostatistics, University of Alabama at Birmingham, Alabama 35294, USA

8 Department of Basic Medical Science, School of Medicine, University of Missouri-Kansas City, 2411 Holmes Street, Kansas City, MO 64108

9 Shunde Hospital of Southern Medical University (The First People's Hospital of Shunde), No.1 of Jiazi Road, Lunjiao, Shunde District, Foshan City, Guangdong Province, China

\# These authors contributed equally to this work. Correspondence should be addressed to Hong-Wen Deng (hdeng2@tulane.edu), Jie Shen (shenjiedr@163.com) and Hong-Mei Xiao (hmxiao@csu.edu.cn). 
medRxiv preprint doi: https://doi.org/10.1101/2020.03.16.20037077; this version posted March 27, 2020. The copyright holder for this preprint (which was not certified by peer review) is the author/funder, who has granted medRxiv a license to display the preprint in It is made available under a CC-BY-NC-ND 4.0 International license .

\section{Abstract}

2 Although gut microbiota influences osteoporosis risk, the individual species involved,

3 and underlying mechanisms, are unknown. We performed integrative analyses in a

4 Chinese cohort with metagenomics/targeted metabolomics/whole-genome

5 sequencing. Bacteroides vulgatus was found negatively associated with bone mineral

6 density (BMD), this association was validated in US Caucasians. Serum valeric acid

7 was positively associated with BMD, and B.vulgatus causally downregulated it.

8 Ovariectomized mice fed B.vulgatus had decreased bone formation and increased

9 bone resorption, lower BMD and poorer bone micro-structure. Valeric acid suppressed

$10 \quad \mathrm{NF}-\kappa \mathrm{B}$ p65 protein production (pro-inflammatory), and enhanced IL-10 mRNA

11 expression (anti-inflammatory), leading to suppressed maturation of osteoclast-like

12 cells, and enhanced maturation of osteoblasts in vitro. B.vulgatus and valeric acid

13 represent promising targets for osteoporosis prevention/treatment. 
medRxiv preprint doi: https://doi.org/10.1101/2020.03.16.20037077; this version posted March 27, 2020. The copyright holder for this

preprint (which was not certified by peer review) is the author/funder, who has granted medRxiv a license to display the preprint in

It is made available under a CC-BY-NC-ND 4.0 International license .

1 Osteoporosis (OP), mainly characterized by low bone mineral density (BMD),

2 predisposes to osteoporotic fracture, and is most prevalent in postmenopausal women

3 (termed postmenopausal osteoporosis (PMOP)). 4.9 million post-menopausal women

4 in US had osteoporotic fractures between 2000 and 2011, with greater hospital costs

5 than myocardial infarction, stroke, and breast cancer ${ }^{1,2}$. The pathogenic mechanisms

6 for PMOP and OP remain unclear, and current intervention and treatment options are

7 not satisfactory ${ }^{1,2}$.

8

9 Human studies have focused on the potential impact of inherent (e.g., (epi-)genome,

10 transcriptome, proteome, metabolome) and external (e.g., environmental,

11 medical/medication/nutrition, lifestyle) risk factors for OP ${ }^{3}$. Recently, however,

12 experimental animal models have identified strong associations between gut

13 microbiota (GM) and bone ${ }^{4}$. For example, Sjogren et al. found that absence of GM in

14 mice leads to increased bone mass that normalizes following GM colonization ${ }^{5}$. In

15 humans, four studies suggested the potential importance of GM for bone health ${ }^{6-9}$,

16 however, these studies had small sample sizes and did not identify specific bacterial

17 species and associated functional mechanisms.

19 To identify specific significant gut bacterial species and their functional mechanisms on bone health, we performed a novel systematic integrative multi-omics analysis of

21 the human genome, GM and targeted metabolome [serum short chain fatty acids

(SCFAs)] in 517 peri- and post-menopausal Chinese women. We identified several 
medRxiv preprint doi: https://doi.org/10.1101/2020.03.16.20037077; this version posted March 27, 2020. The copyright holder for this preprint (which was not certified by peer review) is the author/funder, who has granted medRxiv a license to display the preprint in It is made available under a CC-BY-NC-ND 4.0 International license .

1 bacterial species SCFAs and functional pathways that significantly impacted BMD.

2 We validated the major results in US Caucasians and investigated causal roles of

3 individual bacterial species and SCFAs in regulating bone metabolism in vitro in cells

4 and in vivo in mice. Our work is the first to identify individual BMD-associated GM

5 species and particularly GM-derived functional metabolites in humans, and establish

6 specific pathogenic mechanisms by which GM influences OP risk. Our results lay a

7 foundation for potential prevention/intervention/treatment of OP through GM and 8 metabolome alteration.

\section{Chinese study cohort characteristics}

517 peri-/post-menopausal Chinese women were randomly recruited from Guangzhou

City, China; $84 \%$ were post-menopausal and $16 \%$ peri-menopausal, based on years since menopause (YSM) ${ }^{10}$. Mean YSM and follicle stimulating hormone (FSH) levels were 1.96 years and $76.24 \mathrm{mIU} / \mathrm{mL}$, respectively (Table 1). Age (mean \pm standard deviation $[\mathrm{SD}], 52.85 \pm 2.92$ years $)$ and body mass index (BMI) $(22.97 \pm$ $2.87 \mathrm{~kg} / \mathrm{m}^{2}$ ) were relatively homogeneous. Mean BMD of the lumbar spine (L1-L4), left total hip (HTOT, including femoral neck, trochanter, and inter-trochanter), femoral neck (FN), and ultra-distal radius and ulna (UD-RU) were $1.05 \mathrm{~g} / \mathrm{cm}^{2}, 0.93$ $\mathrm{g} / \mathrm{cm}^{2}, 0.86 \mathrm{~g} / \mathrm{cm}^{2}$, and $0.40 \mathrm{~g} / \mathrm{cm}^{2}$, respectively. Based on WHO criteria, $54.5 \%$ of the subjects had normal BMD (T-score $\geq-1)$, 38.5\% osteopenia $(-2.5<$ T-score $<-1)$, and

$217 \%$ OP $($ T-score $\leq-2.5)$. Lifestyle factors (e.g., alcohol consumption, smoking, calcium supplementation, exercise) and socioeconomic status (e.g., education and 
medRxiv preprint doi: https://doi.org/10.1101/2020.03.16.20037077; this version posted March 27, 2020. The copyright holder for this preprint (which was not certified by peer review) is the author/funder, who has granted medRxiv a license to display the preprint in It is made available under a CC-BY-NC-ND 4.0 International license

1 family annual income) are shown in Extended Data (ED) Table 1. Stool DNA and

2 blood samples were collected for metagenomic, genomic, and metabolomic analyses.

3

\section{Correlation between GM and BMD}

$5 \quad$ We performed shotgun metagenomics sequencing on stool DNA samples and obtained

$\sim 7.35 \mathrm{Gbp} /$ sample sequencing data on average. We calculated unigene (non-redundant genes) counts at different sample sizes. The number of unigenes increased with sample size, approaching a plateau (exceeded $7 \times 10^{6}$ ) with our study sample (Figure 1a), indicating that our sample size was appropriate, large and reasonably powerful for this investigation.

We identified 10,303 species by taxonomy annotation (ftp://ftp.ncbi.nlm.nih.gov/blast/db/FASTA/nr.gz). 62 species were non-rare (relative abundance $>0.10 \%{ }^{11}$ accounting for $61.02 \%$ of the whole GM. The rest were rare species (Figure 1b). The 3 most common species were Faecalibacterium prausnitzii (8.77\%), Bacteroides vulgatus (7.46\%), and Bacteroides fragilis (4.16\%). 26 and 27 of the non-rare species had high positive (Spearman correlation coefficients $[\gamma$ 's] $>$ $0.80, p$-values $<0.001)$ and negative $(\gamma$ 's $<-0.30, p$-values $<0.001)$ correlations, respectively, with one another (Figure 1c). This suggests that interactions between GM species promote co-existence (when $\gamma$ is $>0.80$ ) or suppression (when $\gamma$ is < $-0.30)$ of each other. 
medRxiv preprint doi: https://doi.org/10.1101/2020.03.16.20037077; this version posted March 27, 2020. The copyright holder for this preprint (which was not certified by peer review) is the author/funder, who has granted medRxiv a license to display the preprint in It is made available under a CC-BY-NC-ND 4.0 International license .

1 We used "vegan” package and Microbiome Regression-based Kernel Association Test

2 (MiRKAT) ${ }^{12}$ to calculate $\alpha$-diversity (Shannon index) and $\beta$-diversity (optimal kernel,

3 based on weighted and unweighted UniFrac distance matrices and Bray-Curtis

4 distance), and evaluated their associations with BMD. GM biodiversity was

5 negatively associated with forearm BMD (ED Table 2), including ultra-distal radius

6 BMD (UD-R BMD, partial $\gamma=-0.081, p$-value $=0.072, p$-value of MiRKAT $=0.005)$,

7 ultra-distal ulna BMD (UD-U BMD, partial $\gamma=-0.098, p$-value $=0.029, p$-value of

$8 \quad$ MiRKAT $=0.014)$, and UD-RU BMD (partial $\gamma=-0.097, p$-value $=0.031, p$-value of

9 MiRKAT $=0.010)$. The $p$-value significance remained when adjusted with false discovery rate for multiple testing ( $q$-values $\sim 0.10$ or less). Although no significant 11 association was found between GM biodiversity and BMD at L1-L4 or HTOT, we hypothesized that individual bacterial species contributed to these phenotypes.

We performed constrained linear regression analysis ${ }^{13}$, and found several individual species significantly associated with BMD (ED Table 3). Specifically, Bacteroides vulgatus (regression coefficient $[\beta]=-0.027, p$-value $=0.032$ ), Bacteroides thetaiotaomicron $(\beta=0.027, p$-value $=0.021)$, Butyrate-producing bacterium_SS3/4

$18(\beta=-0.024, p$-value $=0.040)$, Clostridium bolteae $(\beta=0.045, p$-value $=0.036)$, and Bacteroides sp_9_1_42faa $(\beta=0.033, p$-value $=0.031)$ were associated with L1-L4 BMD. Additionally, Butyrate-producing bacterium_SS3/4 was associated with HTOT $\operatorname{BMD}(\beta=-0.022, p$-value $=0.009)$ and $\operatorname{FN~BMD~}(\beta=-0.021, p$-value $=0.014)$;

Bacteroides ovatus was associated with UD-RU BMD $(\beta=0.011, p$-value $=0.046)$; 
medRxiv preprint doi: https://doi.org/10.1101/2020.03.16.20037077; this version posted March 27, 2020. The copyright holder for this

preprint (which was not certified by peer review) is the author/funder, who has granted medRxiv a license to display the preprint in

It is made available under a CC-BY-NC-ND 4.0 International license .

1 and Bacteroides intestinalis was associated with HTOT BMD $(\beta=-0.021, p$-value $=$

$20.043)$.

3 After function annotation and obtaining KEGG modules, we performed partial

4 Spearman correlation analysis to identify relationships between GM functional

5 capacity and BMD variation. Three functional modules were significantly negatively

6 associated with L1-L4 BMD and four modules were negatively associated with

7 UD-RU BMD ( $\gamma$ 's $<-0.10, p$-values $<0.010$ ) (Table 2). For example, for L1-L4 BMD,

8 significantly associated modules included "M00002: glycolysis, core module

9 involving three-carbon compounds", "M00048: inosine monophosphate biosynthesis,

10 phosphoribosylpyrophosphate + glutamine $\rightarrow$ inosine monophosphate", and "M00855:

11 glycogen degradation, glycogen $\rightarrow$ glucose-6P”. All these modules involve pathways

12 whereby GM produces metabolites from ingested foods, suggesting that these

13 metabolites influence BMD.

\section{SCFAs significantly associated with BMD}

16 GM may affect host health through SCFAs ${ }^{14}$. Therefore, we analyzed serum SCFA levels by targeted metabolomics. By multiple linear regression analysis, valeric acid was positively associated with L1-L4 BMD $(\beta=0.040, p$-value $=0.029)$. The results

19 (non-significant) of other kinds of SCFAs (including caproic acid, isovaleric acid,

20 butyric acid, acetic acid, and isobutyric acid) were shown in ED Table 4. Furthermore,

21 five bacterial species were significantly associated with valeric acid (ED Table 5).

22 Alistipes putredinis, Bacteroides caccae, and Bacteroides cellulosilyticus were 
medRxiv preprint doi: https://doi.org/10.1101/2020.03.16.20037077; this version posted March 27, 2020. The copyright holder for this

preprint (which was not certified by peer review) is the author/funder, who has granted medRxiv a license to display the preprint in

It is made available under a CC-BY-NC-ND 4.0 International license .

1 positively associated with valeric acid $(\beta$ 's $>0.05, p$-values $<0.05$, ED Table 5).

2 B.vulgatus and B.intestinalis, which were negatively associated with L1-L4 and

3 HTOT BMDs (ED Table 3), were also negatively associated with valeric acid ( $\beta$ 's <

$4-0.10, p$-values $<0.01$, ED Table 5). Since only B.vulgatus was significantly

5 associated with both L1-L4 BMD and valeric acid, we subsequently focused on this

6 species.

7

8 Since valeric acid is produced by probiotic bacteria ${ }^{15}$, we calculated the Spearman

9 correlation between B.vulgatus and common probiotic bacteria 16, 17. The relative abundance of B.vulgatus was negatively associated $\left(\gamma=-0.24, p\right.$-value $\left.=8.3 \times 10^{-8}\right)$ with the sum of relative abundance of common probiotic bacteria (each still rare $(<$ $0.10 \%$ ) so pooled for analyses). We used Mendelian randomization (MR) approach ${ }^{18}$ to assess the potential causality of B.vulgatus (as exposure) on valeric acid (as outcome), using their associated SNPs derived from whole genome sequencing for human subjects as instrumental variables. Most MR methods, including the weighted median method, maximum likelihood estimation, and inverse-variance weighted indicated that B.vulgatus may causally down-regulate valeric acid $(\beta$ 's $<-0.07$, $p$-values $<0.05)($ ED Table 6$)$. MR-Egger $($ intercept $)$ result $(p$-value $=0.517)$ showed no horizontal pleiotropy for B.vulgatus to influence valeric acid levels.

\section{B.vulgatus/BMD associations in US Caucasians}

To assess the robustness of our major findings, we tested associations between 
medRxiv preprint doi: https://doi.org/10.1101/2020.03.16.20037077; this version posted March 27, 2020. The copyright holder for this preprint (which was not certified by peer review) is the author/funder, who has granted medRxiv a license to display the preprint in It is made available under a CC-BY-NC-ND 4.0 International license .

1 B.vulgatus and human BMD in an independent cohort of 59 post-menopausal

2 Caucasian females, aged $\geq 60$ years, in New Orleans, Louisiana. Mean (SD) age and

3 BMI were $66.98(5.65)$ years and $27.84(8.50) \mathrm{kg} / \mathrm{m}^{2}$, respectively. Mean BMD for

4 L1-L4, HTOT, FN, UD-R, and UD-U were $0.92 \mathrm{~g} / \mathrm{cm}^{2}, 0.80 \mathrm{~g} / \mathrm{cm}^{2}, 0.67 \mathrm{~g} / \mathrm{cm}^{2}, 0.37$

$5 \mathrm{~g} / \mathrm{cm}^{2}$, and $0.28 \mathrm{~g} / \mathrm{cm}^{2}$, respectively. Lifestyle information is shown in ED Table 7. We

6 detected an association between B.vulgatus and HTOT BMD $(\beta=-0.018, p$-value $=$

7 0.029), supporting B.vulgatus's association with BMD in ethnically distinct

8 populations.

In vivo and in vitro validation

11 To evaluate potential causal effects of B.vulgatus on bone metabolism (focusing on lumbar vertebrae), we ovariaectomized (OVX) 8-week-old female C57BL/6 mice ( $\mathrm{n}=$ 18) to model post-menopause, and performed oral gavage experiments. After gavaging with B.vulgatus/normal saline (NS) for eight weeks after OVX, we found lower BMD ( $p$-value $<0.05$, Figure 2a), increased disconnection and separation of the trabecular bone network, and reduction of trabecular number (Figure 2d and Figure 2e) in the B.vulgatus treated group. The B.vulgatus treated group also showed lower (two-sample t-test, $p$-value $<0.05$ ) bone formation levels (measured by serum osteocalcin, Figure $2 \mathrm{~b}$ ) and higher (two-sample t-test, $p$-value $<0.05$ ) bone resorption levels (measured by type I collagen serum C-telopeptide, Figure 2c). This 21 demonstrates that B.vulgatus suppressed bone formation and promoted bone resorption leading to reduced lumbar vertebral $\mathrm{BMD}$ and deteriorated bone 
medRxiv preprint doi: https://doi.org/10.1101/2020.03.16.20037077; this version posted March 27, 2020. The copyright holder for this preprint (which was not certified by peer review) is the author/funder, who has granted medRxiv a license to display the preprint in It is made available under a CC-BY-NC-ND 4.0 International license .

1 architecture.

3 Since our results suggested that B.vulgatus affects BMD by down-regulating valeric

4 acid production, we investigated the effects of valeric acid on osteoclast and

5 osteoblast differentiation in vitro. Murine macrophages (RAW264.7) and

6 pre-osteoblasts (MC3T3-E1) were differentiated with/without valeric acid. After

$7 \quad$ inducing osteoclast differentiation of RAW264.7 cells with RANKL (50 ng/mL), 5

8 days treatment with valeric acid $(1 \mathrm{mM})$ significantly decreased the proportion of

9 mature osteoclast-like cells (TRAP positive and with $\geq 3$ nuclei) vs. controls (Figure

3a), indicating that valeric acid significantly inhibited osteoclast differentiation.

11 Treatment with valeric acid $(1 \mathrm{mM})$ for 14 days also significantly increased

12 differentiation of MC3T3-E1 into osteoblasts, and mineralization of the extracellular matrix (Figure 3b). Therefore, valeric acid inhibited differentiation of osteoclast-like cells, and promoted differentiation of, and mineralization by, osteoblasts.

Because inflammatory pathways play important roles in bone metabolism ${ }^{19}$ and GM may influence bone metabolism through its effects on inflammation ${ }^{4}$, we measured expression levels of several critical inflammatory genes (e.g., NF-кB p65 and IL-10)

19 in cultured osteoclast-like cells and osteoblasts. After treating osteoclast-like cells and osteoblasts with valeric acid for 5 and 14 days, respectively, IL-10 (anti-inflammatory

21 cytokine) mRNA levels were significantly increased, while NF- $\mathrm{B}$ p65

22 (pro-inflammatory) protein levels were decreased, compared to controls (Figures $3 \mathrm{c}$ to 
medRxiv preprint doi: https://doi.org/10.1101/2020.03.16.20037077; this version posted March 27, 2020. The copyright holder for this

preprint (which was not certified by peer review) is the author/funder, who has granted medRxiv a license to display the preprint in

It is made available under a CC-BY-NC-ND 4.0 International license .

$13 \mathrm{f})$. NF- $\mathrm{kB}$ p65 is a subunit of NF- $\mathrm{B}$, plays a critical role in the pathogenesis of

2 multiple chronic inflammatory diseases by upregulating transactivation of

3 inflammatory cytokines target genes ${ }^{20}$; while IL-10 is an anti-inflammatory cytokine

421 . Thus, valeric acid inhibited inflammatory responses of osteoclast-like cells and

5 osteoblasts, which may explain its positive association with BMD, since inflammation

6 may lead to bone loss ${ }^{19}$, and the NF- $\mathrm{kB}$ can inhibit osteoblast functions ${ }^{22}$.

7

8

\section{Discussion}

We found that: 1) GM biodiversity was negatively associated with forearm BMD; 2) several individual bacterial species were significantly associated with BMD; 3) B.vulgatus was negatively associated with BMD in ethnically distinct populations; 4) several bacterial metabolic pathways were negatively associated with BMD; 5) serum valeric acid levels were positively associated with L1-L4 BMD; 6) B.vulgatus was negatively associated with serum valeric acid levels; and 7) B.vulgatus may causally suppress valeric acid levels, presumably by inhibiting growth of valeric acid producing bacteria within the gut.

Subsequent in vivo and in vitro studies found that 1) bone formation was decreased, and bone resorption increased, in OVX female mice fed B.vulgatus; 2) valeric acid suppressed maturation of osteoclast-like cells, and promoted maturation of osteoblasts and extracellular matrix mineralization by osteoblasts in vitro; 3) valeric acid treatment of osteoclast-like cells and osteoblasts in vitro suppressed NF- $\mathrm{B}$ p65 
medRxiv preprint doi: https://doi.org/10.1101/2020.03.16.20037077; this version posted March 27, 2020. The copyright holder for this

preprint (which was not certified by peer review) is the author/funder, who has granted medRxiv a license to display the preprint in

It is made available under a CC-BY-NC-ND 4.0 International license .

1 protein production (pro-inflammatory), and enhanced IL-10 mRNA expression

2 (anti-inflammatory). Thus, B.vulgatus appears to decrease BMD by reducing valeric

3 acid production within the gut, resulting in enhanced inflammation and osteoclast

4 activity, and reduced osteoblast activity.

6 The negative association between GM biodiversity and BMD in our discovery sample

7 is consistent with previous reports. Wang et al. found elevated diversity in OP and

8 osteopenia groups compared with controls ${ }^{8}$, and Das et al. found a trend of higher

9 Shannon index ( $\alpha$-diversity) in OP and osteopenia groups compared with controls (Fig

$3 \mathrm{D}$ in ${ }^{6}{ }^{6}$. Germ-free mice (no GM biodiversity exists) had higher bone mass than

11 mice with normal GM ${ }^{5}$, and that antibiotic treatment of mice early in life reduced

12 GM biodiversity and increased bone size ${ }^{23}$. Although GM biodiversity is generally

13 believed to be beneficial ${ }^{24}$, the above results suggest that the effects of GM

14 biodiversity on health vary with the trait studied, environmental factors (e.g. diet and exercise) and individual species composition within GM.

In our study, B.vulgatus was negatively associated with L1-L4 BMD in the Chinese cohort $(\beta=-0.027, p$-value $=0.032)$, which has a consistent association with HTOT BMD in the US cohort $(\beta=-0.018, p$-value $=0.029)$. In fact, B.vulgatus tended to be consistently negatively (though non-significantly in many cases) associated with BMDs at all the measured various other skeletal sites in both of the two human cohorts (ED Table 8). To evaluate the overall effects of B.vulgatus on BMD, we 
medRxiv preprint doi: https://doi.org/10.1101/2020.03.16.20037077; this version posted March 27, 2020. The copyright holder for this preprint (which was not certified by peer review) is the author/funder, who has granted medRxiv a license to display the preprint in It is made available under a CC-BY-NC-ND 4.0 International license .

1 further performed one-sided sign test ${ }^{25}$ based on the coefficients of the regression of

2 individual skeletal sites with B.vulgatus (ED Table 8). The null hypothesis (H0) is that

3 regression coefficients are equal to zero. The alternative hypothesis (H1) is that

4 regression coefficients are less than zero. The results indicated clearly that overall,

5 there were significant negative associations between BMDs and B.vulgatus in both of

6 the Chinese and the US cohorts $\left(p\right.$-value_Chinese $=4.8 \times 10^{-7}, p$-value_US $=9.8$

$7 \times 10^{-4}$ ). In genomics studies, it is not uncommon to observe that a particular gene

8 was significantly associated with different skeletal sites of BMDs in different

9 populations. An example is given by the most prominent WNT16 gene, which was

10 found to be associated with BMD at different skeletal sites in different cohorts ${ }^{26}$. The

11 association and partial validation between B.vulgatus and BMD in the human cohorts

12 was only mainly for discovery relative to the following-up functional validation

13 studies. Following discoveries in humans, we subsequently validated the results by

14 various in vivo and in vitro experiments. All of the results together furnish strong

15 evidence for the significance of B.vulgatus on BMD and bone metabolism.

B.vulgatus is one of the most abundant bacteria in human gut ${ }^{27}$, and can trigger proinflammatory NF- $\mathrm{BB}$ signaling pathways ${ }^{27}$ associated with bone remodeling ${ }^{28}$. To determine how GM influences BMD, we examined relationships between GM functional capacity and BMD variation. Most GM functional modules negatively associated with BMD (Table 2) involved GM metabolism. M00002, M00003 and M00855 involved glycolytic pathways or gluconeogenesis, both of which affect 
medRxiv preprint doi: https://doi.org/10.1101/2020.03.16.20037077; this version posted March 27, 2020. The copyright holder for this

preprint (which was not certified by peer review) is the author/funder, who has granted medRxiv a license to display the preprint in

It is made available under a CC-BY-NC-ND 4.0 International license .

1 glucose metabolism, essential for cellular energy ${ }^{29}$. Modules M00048 and M00050

2 both involve nucleic acid synthesis required for bacterial growth ${ }^{30,}{ }^{31}$. These

3 collective findings demonstrate that human bone health is affected by GM, and that

4 specific bacterial biosynthetic/metabolic pathways, contribute to these effects.

6 Since several GM functional modules were associated with BMD, and microbial

7 metabolites contribute to host-microbiome interactions ${ }^{32}$, we explored relationships

8 between BMD and serum SCFAs. SCFAs are produced exclusively by GM ${ }^{15}$,

9 absorbed in the colon ${ }^{15}$, and function as critical signalling molecules between the host

10 and GM ${ }^{15}$. Regarding the potential impact of SCFAs on bone health, butyrate has

11 been reported to inhibit osteoclast differentiation and bone resorption in mice ${ }^{14,33}$. In

12 the current study, we found that valeric acid (an SCFA) was positively associated with

13 BMD, inhibited differentiation of osteoclast-like cells, and promoted differentiation

14 and mineralization of osteoblasts. Valeric acid also suppressed NF- $\kappa B$ p65 protein

15 production (pro-inflammatory), and enhanced expression of IL-10 mRNA

16 (anti-inflammatory) by osteoclast-like cells and osteoblasts. This is consistent with

17 previous reports that SCFAs reduced macrophage induced inflammation by

18 suppressing $\mathrm{NF}-\kappa \mathrm{B}$, and increasing IL-10, expression ${ }^{34}$. IL-10 inhibits NF- $\kappa \mathrm{B}$

19 production ${ }^{35}$, and NF- $\kappa \mathrm{B}$ promotes inflammation, which contributes to bone loss ${ }^{19}$,

20 and inhibits osteoblasts, which reduces new bone formation ${ }^{22}$. These collective

21 results are consistent with the conclusion that the protective effect of valeric acid on

22 BMD is partially attributable to decreased osteoclast activity and increased osteoblast 
medRxiv preprint doi: https://doi.org/10.1101/2020.03.16.20037077; this version posted March 27, 2020. The copyright holder for this

preprint (which was not certified by peer review) is the author/funder, who has granted medRxiv a license to display the preprint in

It is made available under a CC-BY-NC-ND 4.0 International license .

1 activity through increased IL-10 expression, and direct (via valeric acid) or indirect

2 (via IL-10) inhibition of NF- $\mathrm{B}$ expression ${ }^{28}$. Valeric acid inhibits histone deacetylase

3 (HDAC), an enzyme that is important for epigenomic regulation of gene expression ${ }^{36}$.

4 HDAC is implicated in the pathogenesis of a number of diseases (e.g., cancer, colitis,

5 cardiovascular disease and neurodegeneration), and HDAC inhibitors are considered

6 as potential therapeutic agents ${ }^{36}$. In irradiated mice, valeric acid can protect

7 hematogenic organs, improve gastrointestinal tract function and enhance intestinal

8 epithelial integrity to elevate survival rate ${ }^{37}$. Our study here for the first time suggest

9 that valeric acid could be used to treat/prevent OP.

11 Since both B.vulgatus and valeric acid were associated with BMD, we sought to

12 determine whether B.vulgatus regulated bone metabolism by decreasing valeric acid levels. Regression and MR analyses demonstrated that B.vulgatus was negatively associated with valeric acid, and may causally down-regulate valeric acid levels. We also observed negative correlations between B.vulgatus and common gut probiotic bacteria ${ }^{16,17}$. Bacterial fermentation product levels (e.g., valeric acid) depend on the relative abundances of different GM populations, and on competitive and cooperative interactions between different GM species ${ }^{38}$. GM in humans is dominated by negative

19 interactions, and the Bacteroidales, which includes B.vulgatus, commonly express molecular mechanisms for delivering toxic payloads to other bacteria ${ }^{39}$. Consequently, we speculate that B.vulgatus competitively inhibits growth of valeric acid producing probiotic bacteria, thereby reducing valeric acid levels. 
medRxiv preprint doi: https://doi.org/10.1101/2020.03.16.20037077; this version posted March 27, 2020. The copyright holder for this

preprint (which was not certified by peer review) is the author/funder, who has granted medRxiv a license to display the preprint in

It is made available under a CC-BY-NC-ND 4.0 International license .

2 In this study, we pioneered an innovative and comprehensive multi-omics approach

3 for discovery in a Chinese cohort, followed by in vitro and in vivo functional

4 validation experiments plus replication in an independent cohort of US Caucasians.

5 We, for the first time, successfully identified and validated individual gut bacterial

6 species, and their derived metabolites, that were significantly associated with human

7 BMD. These findings provide a potential novel target and pathway for OP prevention

8 and treatment during the critical menopausal period in aging women.

10 There are several strengths of our study. First, to our knowledge, this is currently the

11 largest metagenomics study directly testing associations between GM and human

BMD. Second, we used stringent inclusion and exclusion criteria to ensure that

13 subjects were relatively homogeneous for age, ovarian function and living

14 environment, thereby minimizing potential confounding factors. Third, functional

15 mechanisms contributing to associations between GM and BMD were identified by

16 using an innovative multi-omics approach to generate a comprehensive understanding

17 of crosstalk, interactions, and causal inference of the interactions, between GM and

18 human BMD. Finally, we used both statistical and experimental evidences to

19 demonstrate the effects of specific bacterial species and GM-derived metabolites on

20 BMD variation and regulation, and the causal effects of specific gut bacterial species

21 on GM-derived metabolites in human serum. 
medRxiv preprint doi: https://doi.org/10.1101/2020.03.16.20037077; this version posted March 27, 2020. The copyright holder for this

preprint (which was not certified by peer review) is the author/funder, who has granted medRxiv a license to display the preprint in

It is made available under a CC-BY-NC-ND 4.0 International license .

1 In conclusion, our study provides compelling evidence for associations between GM,

2 SCFAs and human BMD. Importantly, we demonstrated that B.vulgatus appears to

3 play a critical role in regulating bone metabolism, through its effects on valeric acid

4 production. Valeric acid, in turn, promotes differentiation and mineralization of

5 osteoblasts, and suppresses osteoclast differentiation and inflammatory responses by

6 osteoblasts and osteoclast-like cells. Our findings provide novel insights into the

7 pathophysiological mechanisms of OP from a novel perspective of human microbiota

8 and their functional products, SCFAs, in human serum and suggested potential new

9 biomarkers (e.g., valeric acid) and treatment targets (e.g., elimination of B.vulgatus

10 from the gut; dietary supplementation with valeric acid) for OP

11 prevention/intervention/treatment.

Online Methods

Subjects recruitment and sample preparation

This study was approved by the Third Affiliated Hospital of Southern Medical University (Guangzhou City, China). It was performed under the principle of the Helsinki Declaration II. 517 independent unrelated peri-/post-menopausal Chinese women were recruited. The inclusion criteria included 1) aged 40 years or older, 2) being in menopause stage, and 3) had lived in Guangzhou City for at least three months. Menopause is marked by the cessation of menstruation, where peri-menopause is a transition phase beginning at a woman's last menstrual cycle and continuing through the following 12 months without a menstrual cycle; once there are 
medRxiv preprint doi: https://doi.org/10.1101/2020.03.16.20037077; this version posted March 27, 2020. The copyright holder for this preprint (which was not certified by peer review) is the author/funder, who has granted medRxiv a license to display the preprint in It is made available under a CC-BY-NC-ND 4.0 International license .

1 no menstrual cycles for 1 year, we term it post-menopause ${ }^{10}$. Briefly, exclusion

2 criteria included the use of antibiotics, oestrogens, or anticonvulsant medications

3 which may affect gut microbiota (GM) composition and/or bone metabolism in the

4 past three months, as well as other diseases that could lead to secondary osteoporosis

5 (OP). A detailed list of exclusion criteria is shown in Extended Data (ED) Table 9. We

6 obtained signed informed consent from each subject before enrolling them into this

7 study. Each subject filled out a questionnaire that collected information on age,

8 medical history, family history, physical activity, alcohol consumption, diet habits,

9 smoking history, nutrition supplements, etc.

10 We used a GE Lunar dual energy X-ray absorptiometry (DXA, GE Healthcare,

11 Madison, WI, USA, version 13.31.016) with a standard scan model to measure the

12 bone mineral density (BMD) of each subject at various skeletal sites, including the

13 lumbar spine (L1-L4), left total hip (HTOT), femoral neck (FN), ultra-distal radius

14 and ulna (UD-RU). We performed DXA scanner calibration with a daily special

15 phantom scan for quality assurance. The accuracy of various skeletal sites BMD

16 measurement was assessed by the coefficient of variation $(\mathrm{CV} \%)$ of spine $\mathrm{BMD}$,

17 which was $0.89 \%$.

18 Blood and stool samples were collected from each subject. Blood samples were

19 collected after an overnight fast for $>8$ hours, and used for serum analysis and DNA

20 extraction with the SolPure DNA Kit (Magen, Guangzhou, China). Each faecal

21 sample was frozen at $-80{ }^{\circ} \mathrm{C}$ within 30 min of sample procurement, and used for GM

22 DNA extraction with the E.Z.N.A. ${ }^{\circledR}$ Stool DNA Kit (Omega, Norcross, GA, USA). 
medRxiv preprint doi: https://doi.org/10.1101/2020.03.16.20037077; this version posted March 27, 2020. The copyright holder for this preprint (which was not certified by peer review) is the author/funder, who has granted medRxiv a license to display the preprint in It is made available under a CC-BY-NC-ND 4.0 International license

1 We stored the serum, blood and GM DNA samples at $-80^{\circ} \mathrm{C}$ until further analyses.

2

3 Metagenomic shotgun sequencing and annotation

4 DNA library construction

5 Shotgun metagenomic sequencing was performed by LC-Bio Technologies

6 (Hangzhou) CO., LTD. (Hangzhou, China, www.lc-bio.com; this company owns an

7 LC Sciences R\&D department in Houston, TX, USA, www.lcsciences.com). We

8 constructed a faecal DNA library, and used Hiseq 4000 (Illumina, San Diego, CA,

9 USA) and PE150 strategy to conduct metagenomic shotgun sequencing. The relative reference

based

on

the

KEGG

dataset

21 (https://www.genome.jp/kegg/pathway.html) for functional annotation. The relative abundance of each annotated functional module was the sum of relative abundance of 
medRxiv preprint doi: https://doi.org/10.1101/2020.03.16.20037077; this version posted March 27, 2020. The copyright holder for this

preprint (which was not certified by peer review) is the author/funder, who has granted medRxiv a license to display the preprint in

It is made available under a CC-BY-NC-ND 4.0 International license .

1 the unigenes within this module. We chose the modules whose relative abundance $>$

$20.10 \%$ to estimate the association between the KEGG modules and BMD variation by

3 performing partial Spearman correlation analysis, and adjusted for a number of

4 covariates, including age, body mass index (BMI), years since menopause (YSM),

5 follicle stimulating hormone (FSH), exercise, and family annual income. Results with

$6 \quad p$-values $<0.01$ were considered statistically significant.

7 Detailed information about faecal DNA library construction, raw data preprocessing

8 and cleaning, taxonomic and functional annotation of unigenes, was shown in

9 supplementary information.

\section{Unigene accumulation curve construction and species biodiversity calculation}

We first counted the number of unigenes at different sample sizes. The $\mathrm{R}$ package "ggplot2" was used to generate a unigene accumulation curve. We plotted the number of unigenes (Y-axis) against the number of samples (X-axis).

The $\alpha$-diversity of GM was estimated based on the species profile of each sample according to the Shannon index by using R package "vegan". Then, partial Spearman correlation analysis was performed to estimate the association between the Shannon index and BMD variation. The association between bacterial species profiles and BMD variation was calculated by the program Microbiome Regression-based Kernel Association Test (MiRKAT) ${ }^{12}$, by which we first calculated different kinds of kernels (including weighted and unweighted UniFrac distance matrices and Bray-Curtis distance), and then obtained the optimal kernel to estimate the association between 
medRxiv preprint doi: https://doi.org/10.1101/2020.03.16.20037077; this version posted March 27, 2020. The copyright holder for this

preprint (which was not certified by peer review) is the author/funder, who has granted medRxiv a license to display the preprint in

It is made available under a CC-BY-NC-ND 4.0 International license .

1 GM species profiles and BMD variations. In these analyses, we adjusted the same set

2 of covariates as the KEGG modules analysis mentioned above. Results with $p$-values

3 less than 0.05 were considered statistically significant.

5 Measurement of short chain fatty acids (SCFAs)

$62 \mu 1$ of the supernatants extracted from serum samples were analyzed with gas

7 chromatography-tandem mass spectrometry (GC-MS/MS, 7890B-7000D, Agilent

8 Technologies Inc, Santa Clara, CA, USA) by Wuhan Metware Biotechnology Co., Ltd

9 (Wuhan City, China, www.metware.cn) based on a fused silica capillary column

10 (DB-FFAP, $30 \mathrm{~m} \times 0.25 \mathrm{~mm} \times 0.25 \mu \mathrm{m}$, Agilent Technologies Inc, Santa Clara, CA,

11 USA). Then we constructed standard curves to calculate concentration of SCFAs.

12 Detailed conditions of GC-MS/MS, quality control (QC), preparation of SCFAs 13 calibration standards, and SCFAs concentration calculation by standard curves, were 14 shown in supplementary information.

\section{Association analysis among GM, SCFA, and BMD}

We treated BMD as a continuous variable and then explored the association among

GM, SCFA, and BMD by using different association analysis methods. In this study,

19 we focused on non-rare species (relative abundance $>0.10 \%$ ) because rare species typically contribute significantly less to functional diversity than non-rare species due to their low abundances ${ }^{42}$; meanwhile, the rare species are generally difficult to cultivate ${ }^{42}$, which might make our subsequent experimental validation in vivo 
medRxiv preprint doi: https://doi.org/10.1101/2020.03.16.20037077; this version posted March 27, 2020. The copyright holder for this

preprint (which was not certified by peer review) is the author/funder, who has granted medRxiv a license to display the preprint in

It is made available under a CC-BY-NC-ND 4.0 International license .

1 difficult.

2 For the association analysis, first, we used the "igraph" package and the "psych"

3 package of R software to identify correlations between bacterial species. Spearman

4 correlation analysis was performed on the relative abundance of each bacterial species.

5 Meanwhile, we used the same method to identify correlations between specific

6 bacterial species and probiotic bacteria reported in two previous reviews which

7 summarized the most notable probiotics ${ }^{16,}$ 17. The reported probiotic bacteria were

8 pooled for such analyses due to the small relative abundances of each of the

9 individual species (less than $0.10 \%$ ). Furthermore, the R package "pheatmap"

10 package was used to create a heatmap for visualization of the bacterial species

11 correlation.

12 Second, for those highly correlated bacterial species (with correlation coefficients [ $\gamma$ 's]

$13 \geq 0.80)$ that might cause a multiple co-linearity problem, we retained the bacterial

14 species with a higher relative abundance and removed others as bacteria with

15 relatively higher relative abundance may render higher power in association testing.

16 Constrained linear regression analysis ${ }^{13}$ was then performed by using Stata 14

17 software with the "cnsreg" function, in which BMD variation was considered as the

18 dependent variable, and the relative abundance of bacterial species was set as the

19 independent variable. A number of covariates were adjusted in the regression analysis,

20 including age, BMI, YSM, FSH, exercise, and family annual income. The threshold of

21 exercise was 2.5 hours per week based on a published guideline ${ }^{43}$. The family annual

22 income was separated according to the local economic report. As microbiome data are 
medRxiv preprint doi: https://doi.org/10.1101/2020.03.16.20037077; this version posted March 27, 2020. The copyright holder for this preprint (which was not certified by peer review) is the author/funder, who has granted medRxiv a license to display the preprint in It is made available under a CC-BY-NC-ND 4.0 International license .

1 often obtained at different taxonomic ranks (including species, genus, family, order,

2 class and phylum), we performed subcomposition analysis using previously published

3 protocols ${ }^{13}$, and converted the bacterial species relative abundance data into

4 subcompositions within each phylum by centered log ratio transformation, to find out

5 which bacterial species within a given phylum is associated with BMD variation. The

6 formula of constrained linear regression analysis is shown below (Formula 2), where

$7 \quad \mathrm{p}$ was the phylum level, $\mathrm{n}$ was the number of phyla, $\mathrm{s}$ was species level, and $\mathrm{m}$ was

8 the number of bacterial species. Bacterial species with a $p$-value of the regression

9 coefficient $(\beta)$ less than 0.05 were defined as BMD-associated bacterial species.

$$
Y(B M D)=\sum_{p=1}^{n} \sum_{s=1}^{m} \beta_{p s} \operatorname{CLR}\left(X_{p s}\right)+\beta * \text { covariates }
$$

$$
\sum_{s=1}^{m} \beta_{p s}=0
$$

Third, we used multiple linear regression analysis to identify BMD-associated SCFAs

(Formula 3), where we performed log transformation for the SCFA concentration because of their non-normalization distribution and adjusted the same set of covariates mentioned above.

$$
Y(B M D)=\sum \beta_{i} * \log \left(X_{i}\right)+\beta_{\mathrm{j}} * \text { covariates } \mathrm{j}
$$

Finally, we performed constrained linear regression analysis (Formula 4) to identify covariates.

19

$$
Y(\log (\text { individualSCFA }))=\sum_{p=1}^{n} \sum_{s=1}^{m} \beta_{p s} \mathrm{CLR}\left(X_{p s}\right)+\beta * \text { covariates }
$$

$$
\sum_{s=1}^{m} \beta_{p s}=0
$$


3 A total of 59 Caucasian females, aged 60 years or older, were recruited from the

4 ongoing Louisiana Osteoporosis Study (from 2011 to current), which aims to build a

5 large sample pool in greater New Orleans and surrounding areas in Southern

6 Louisiana, USA for investigating genetic and environmental factors for

7 musculoskeletal disorders ${ }^{44}$. This study was approved by the institutional review

8 board of Tulane University (New Orleans, LA, USA), and a written consent form was

9 signed by each participant before data and bio-sample collection. Individuals who had

10 pathological conditions that may influence BMD (e.g., a bilateral oophorectomy,

11 chronic renal failure, liver failure, lung disease, gastrointestinal diseases, and inherited

12 bone diseases), or may influence GM (e.g., taking antibiotics, having gastroenteritis, major surgery involving hospitalization, and inter-continental travel in the past three months) were excluded. For each participant, BMD was measured by using a Hologic Discovery-A DXA machine (Hologic Inc., Bedford, MA, USA) and information on age, medical history, physical activity, alcohol consumption, diet habits, smoking history, and nutrition supplements was assessed by a questionnaire. The accuracy of BMD measurement as assessed by the CV\% of L1-L4 BMD was $0.54 \%$. The shotgun metagenomics sequencing on the collected faecal samples were performed by Alkek Center for Metagenomics and Microbiome Research (CMMR), Baylor College of

21 Medicine. We conducted partial Spearman correlation analysis for the identification of correlation between GM biodiversity and BMD variation, and we also used 
medRxiv preprint doi: https://doi.org/10.1101/2020.03.16.20037077; this version posted March 27, 2020. The copyright holder for this

preprint (which was not certified by peer review) is the author/funder, who has granted medRxiv a license to display the preprint in

It is made available under a CC-BY-NC-ND 4.0 International license .

1 constrained linear regression analysis (Formula 2), as described above, to identify

2 BMD-associated individual bacterial species. The covariates included age, BMI,

3 exercise, and bone fracture.

4

In vivo mouse experiment with B.vulgatus

Ovariectomy (OVX) and B.vulgatus gavage

$7 \quad$ All the procedures involving mice were approved by the Southern Medical University

8 Animal Management Committee (Guangzhou City, China). Seven-week-old female

9 C57BL/6 mice (specific-pathogen free grade) were purchased from the Laboratory

Animal Center of the Southern Medical University (Guangzhou, China). The mice

11 were fed freely with food and water for one week to acclimate to the new

12 environment before experiments. Then bilateral OVX surgery was performed with

13 general anaesthesia by the dorsal approach because eight-week-old C57BL/6J mice

14 are suitable animal model for postmenopausal osteoporosis ${ }^{45}$. After one week for

15 recovery, the mice were separated randomly into two groups (9 samples/group):

16 Group I mice were gavaged with $100 \mu \mathrm{l}$ of B.vulgatus (ATCC8482, $5 \times 10^{8}$

17 colony-forming units/mouse, ATCC, Manassas, VA, USA; lot number: 70009621),

18 while Group II mice were gavaged with $100 \mu$ of normal saline (NS). B.vulgatus was

19 cultivated according to the product description and harvested in log phase for gavage.

20 All mice were gavaged every other day and continued to feed freely with common

21 food and water under the same environmental conditions. After gavaging for eight

22 weeks, the mice were sacrificed and used for blood and bone measurements. 
medRxiv preprint doi: https://doi.org/10.1101/2020.03.16.20037077; this version posted March 27, 2020. The copyright holder for this preprint (which was not certified by peer review) is the author/funder, who has granted medRxiv a license to display the preprint in It is made available under a CC-BY-NC-ND 4.0 International license .

2 BMD measurement and bone morphology evaluation by micro-computed tomography

$3(\mu C T)$

4 We used LaTheta LCT $200 \mu \mathrm{CT}$ (Aloka, Japan) to measure the BMD of the $5^{\text {th }}$ lumbar

5 vertebral body. The instrument accuracy was $1 \pm 0.005 \mathrm{mg} / \mathrm{cm}^{3}$. We performed

6 phantom scan at first for QC. Then we scanned the lumbar spine to obtain lumbar

7 vertebral body BMD. Meanwhile, for visualization and comparison of bone

8 microstructure changes, we randomly selected a bone sample (the $5^{\text {th }}$ lumbar vertebrae)

9 from each of the two mice groups (Group I with B.vulgatus gavage and Group II with

10 NS gavage), and used $\mu$ CT100 (Scanco Medical AG, Bassersdorf, Switzerland) with a

11 resolution of $7.4 \mu \mathrm{m}$ for three-dimensional reconstruction.

Analysis of serum biomarkers

We used ELISA kits to measure osteocalcin (Cloud-Clone Corp, Katy, TX, USA) and C-telopeptide of type I collagen (Cusabio, Houston, TX, USA), which are markers of bone formation and bone resorption, respectively.

Histomorphometry

We used hematoxylin-eosin (ZSGB-BIO, Beijing, China) staining to assess histomorphology of trabecular bone in the $5^{\text {th }}$ lumbar vertebrae. 
medRxiv preprint doi: https://doi.org/10.1101/2020.03.16.20037077; this version posted March 27, 2020. The copyright holder for this

preprint (which was not certified by peer review) is the author/funder, who has granted medRxiv a license to display the preprint in

It is made available under a CC-BY-NC-ND 4.0 International license .

1 We used two-sample t-test to identify whether BMD and serum biomarkers were

2 significantly different between the two groups.

3 Details about scanning parameters of $\mu \mathrm{CT}$ and histomorphometry process were shown

4 in supplementary information.

6 Mendelian randomization (MR) analysis for BMD-associated GM and SCFA

$7 \quad$ Whole genome sequencing (WGS)

8 WGS was performed by BGI Genomics Co. Ltd (Shenzhen, China;

9 https://www.genomics.cn/) with BGISEQ-500 platform.

10 Details including quality control were shown in supplementary information.

Genome-wide association study (GWAS)

We used PLINK 1.9 software with the default criteria as follows to identify B.vulgatus and valeric acid-associated SNPs: the SNPs with missing call rate $<0.1$, minor allele frequencies $>0.01$, and Hardy-Weinberg equilibrium $p$-value $>1.0 \times 10^{-5}$ were included for subsequent analyses.

MR analysis

Based on B.vulgatus and valeric acid GWAS results, we investigated the causality of

B.vulgatus exposure on valeric acid outcome with one-sample MR analysis, which is a commonly used method. One-sample MR analysis uses genetic variants, exposure, and outcome from the same individua, which provides greater control of the analysis 
1 (such as determining exposure category - a continuum or in categories, examining

2 associations between genetic instruments and confounders) than two-sample MR

3 analysis ${ }^{46}$. For the implementation of MR, we first selected independent genetic

4 variants $\left(\mathrm{r}^{2} \leq 0.001\right)$ associated with the B.vulgatus $\left(p\right.$-values $\left.<1 \times 10^{-5}\right)$ as the

5 instrumental variables (IVs) as done earlier ${ }^{47}$. We then obtained the corresponding

6 effect estimates of these SNPs from the valeric acid GWAS analysis. When the target

7 SNPs were not available in the valeric acid GWAS result, we used proxy SNPs that

8 were in high linkage disequilibrium $\left(\mathrm{LD}, \mathrm{r}^{2}>0.80\right)$ with the SNPs of interest. The

9 proxy SNPs were identified based on 1000 genomes project data ${ }^{48}$. To ensure the

10 SNPs used as IVs for B.vulgatus are not in LD with one aother, a vital assumption of

11 MR, we calculated pairwise-LD between all of our selected SNPs in the 1000

12 Genomes European reference sample using PLINK 1.9. For all the pairs of SNPs determined to violate the independence assumption with $\mathrm{r}^{2}>0.01$, we retained only the SNPs with the smaller B.vulgatus association $p$-values. Overall, we obtained 15 LD-independent SNPs that achieved genome-wide significance for B.vulgatus and valeric acid. Therefore, these 15 SNPs remained for performing the MR analysis (Extended Data Table 10). Weighted median method, maximum likelihood estimation (MaxLik) and inverse-variance weighted (IVW) ${ }^{49}$ were performed to identify causal relationships between B.vulgatus and valeric acid by weighting the effect estimate of each SNP on valeric acid with its effect on B.vulgatus. Because SCFA was only produced from GM ${ }^{14}$, we only chose single direction MR (B.vulgatus as exposure and valeric acid as outcome) rather than bidirectional MR analysis. Because the 
medRxiv preprint doi: https://doi.org/10.1101/2020.03.16.20037077; this version posted March 27, 2020. The copyright holder for this

preprint (which was not certified by peer review) is the author/funder, who has granted medRxiv a license to display the preprint in

It is made available under a CC-BY-NC-ND 4.0 International license .

1 presence of horizontal pleiotropy could bias the MR estimates, we used the intercept

2 that deviates from the MR-Egger method to examine the presence of horizontal

3 pleiotropy as described in the previous study ${ }^{47}$.

4

5 Effects of valeric acid on osteoclastogenesis and osteoblastogenesis

6 In vitro differentiation of osteoclast-like cells

7 We used the murine monocyte/macrophage cell line RAW264.7 (Chinese Academy of

8 Sciences Cell Bank, Shanghai, China) as osteoclast precursors, which can

9 differentiate into osteoclast-like cells in the presence of receptor activator of nuclear

10 factor- $\kappa \mathrm{B}$ ligand (RANKL, $50 \mathrm{ng} / \mathrm{mL}$, PEPROTECH, Rocky Hill, NJ, USA). The

11 cells were grown in Dulbecco's Modified Eagle Medium (DMEM,

12 GIBCO/Invitrogen, Carlsbad, CA, USA), containing 10\% fetal bovine serum (FBS,

13 GIBCO/Invitrogen, Carlsbad, CA, USA), $100 \mathrm{U} / \mathrm{ml}$ penicillin and $100 \mathrm{mg} / \mathrm{ml}$

14 streptomycin sulfate (GIBCO/Invitrogen, Carlsbad, $\mathrm{CA}, \mathrm{USA}$ ), at $37^{\circ} \mathrm{C}$ in a

15 humidified atmosphere of $95 \%$ air and $5 \% \quad \mathrm{CO}_{2}$, and treated with various concentrations $(0,0.001,0.01,0.1,1 \mathrm{mM})$ of valeric acid (TCI, Tokyo, Japan). We changed the medium every other day, and fixed the cells at the end of the $5^{\text {th }}$ day.

18 Then we performed tartrate-resistant acid phosphatase (TRAP) staining (Solarbio,

19 Beijing, China) to observe TRAP-positive multinucleated ( $\geq 3$ nuclei) cells.

In vitro differentiation of osteoblasts

MC3T3-E1 cells (Chinese Academy of Sciences Cell Bank, Shanghai, China) were 
medRxiv preprint doi: https://doi.org/10.1101/2020.03.16.20037077; this version posted March 27, 2020. The copyright holder for this preprint (which was not certified by peer review) is the author/funder, who has granted medRxiv a license to display the preprint in It is made available under a CC-BY-NC-ND 4.0 International license .

1 maintained in osteoblastogenic medium (AAPR99-C500, Pythonbio, Guangzhou,

2 China) with $10 \% \mathrm{FBS}, 100 \mathrm{U} / \mathrm{ml}$ penicillin, and $100 \mathrm{mg} / \mathrm{ml}$ streptomycin sulfate at

$3 \quad 37^{\circ} \mathrm{C}$ with $5 \% \mathrm{CO}_{2}$, and treated with various concentrations of valeric acid $(0,0.001$,

$4 \quad 0.01,0.1,1 \mathrm{mM}$ ) for 14 days. Then alkaline phosphatase (Beyotime, Shanghai, China)

5 staining and alizarin red S (Solarbio, Beijing, China) staining were performed

6 according to standard techniques to evaluate osteoblast differentiation and

7 extracellular matrix mineralization, respectively.

9 Gene expression in osteoclast-like cells and osteoblasts

Total protein and RNA were extracted from osteoclast-like cells and osteoblasts to examine expression of the selected genes. Protein concentration was determined by the BCA protein assay kit (Thermo scientific, Rockford, IL, USA). Since NF- $\mathrm{B}$ signaling pathway was reported to activate osteoclastogenesis 28 and inhibit osteoblastogenesis ${ }^{22}$, and SCFAs can suppress this pathway ${ }^{34}$, we explored whether the suppressive effect and stimulating effect of valeric acid on osteoclast-like cells and osteoblasts, respectively, were at least partially through inhibition of the NF- $\mathrm{B}$ signaling pathway. Western blot (WB) analysis was performed with NF- $\kappa$ B signaling pathway-associated primary antibody targeting NF-кB p65 (Bclonal, Beijing, China) in osteoclast-like cells and osteoblasts, and GAPDH (Proteintech, Chicago, IL, USA) was used as a reference protein. After validating the association between valeric acid and the NF- $\mathrm{BB}$ signaling pathway, we further explored whether IL-10 in osteoclast-like cells and osteoblasts contributed to this association. We examined 
medRxiv preprint doi: https://doi.org/10.1101/2020.03.16.20037077; this version posted March 27, 2020. The copyright holder for this preprint (which was not certified by peer review) is the author/funder, who has granted medRxiv a license to display the preprint in It is made available under a CC-BY-NC-ND 4.0 International license .

1 IL-10 because it can be increased by SCFAs ${ }^{34}$ and inhibit activation of NF- $\kappa \mathrm{B}^{35}$.

2 Real-time PCR analysis (SYBR green real time PCR master mix, TOYOBO, Osaka,

3 Japan) was performed for the transcriptional levels of IL-10. Relative expression of

4 IL-10 was normalized to mouse-18S expression, and calculated using the comparative

5 threshold cycle $(\mathrm{Ct})$ method ${ }^{50}$. The primers of IL-10 were

6 GGAGCTGAGGGTGAAGTTTGA (sense) and GACACAGACTGGCAGCCAAA

7 (antisense). The primers of mouse-18S were CGATCCGAGGGCCTCACTA (sense)

8 and AGTCCCTGCCCTTTGTACACA (antisense).

10 Online resources and abbreviations

11 Online resources and abbreviations are provided in supplementary information. 


\section{References:}

1. Singer, A., et al.. Burden of illness for osteoporotic fractures compared with other serious diseases among postmenopausal women in the United States. MAYO CLIN PROC 90, 53-62 (2015). BONE MINER RES 32, 424-430 (2017).

3. Hendrickx, G., Boudin, E. \& Van Hul, W. A look behind the scenes: the risk and pathogenesis of primary osteoporosis. NAT REV RHEUMATOL 11, 462-474 (2015). Bone Health: Potential Mechanisms and Prospective. J CLIN ENDOCR METAB 102, 3635 (2017).

5. Sjogren, K., et al.. The gut microbiota regulates bone mass in mice. $J$ BONE MINER RES 27, $1357-1367$ (2012).

6. Das, M., et al.. Gut microbiota alterations associated with reduced bone mineral density in older adults. Rheumatology (Oxford) (2019).

7. Per-Anders Jansson, et al. Probiotic treatment using a mix of three Lactobacillus strains for lumbar spine bone loss in postmenopausal women: a randomised, double-blind, placebo-controlled, multicentre trial. The Lancet Rheumatology 3, E154-E162 (2019).

8. Wang, J., et al. Diversity analysis of gut microbiota in osteoporosis and osteopenia patients. PEERJ 5, e3450 (2017).

9. Nilsson, A.G., Sundh, D., Backhed, F. \& Lorentzon, M. Lactobacillus reuteri reduces bone loss in older women with low bone mineral density: a randomized, placebo-controlled, double-blind, clinical trial. J INTERN MED 284, 307-317 (2018). 19, 426-429 (2016).

11. Aguilar, P., Dorador, C., Vila, I. \& Sommaruga, R. Bacterioplankton composition in tropical high-elevation lakes of the Andean plateau. FEMS MICROBIOL ECOL 94(2018). Regression-Based Kernel Association Test. AM J HUM GENET 96, 797-807 (2015). 
medRxiv preprint doi: https://doi.org/10.1101/2020.03.16.20037077; this version posted March 27, 2020. The copyright holder for this preprint (which was not certified by peer review) is the author/funder, who has granted medRxiv a license to display the preprint in It is made available under a CC-BY-NC-ND 4.0 International license .

1 14. Lucas, S., et al.. Short-chain fatty acids regulate systemic bone mass and protect from 2 pathological bone loss. NAT COMMUN 9, 55 (2018).

3 15. LeBlanc, J.G., et al.. Beneficial effects on host energy metabolism of short-chain fatty acids and

4 vitamins produced by commensal and probiotic bacteria. MICROB CELL FACT 16, 79 (2017).

5 16. Schepper, J.D., et al.. Probiotics in Gut-Bone Signaling. ADV EXP MED BIOL 1033, 225-247

6 (2017).

7 17. Collins, F.L., Rios-Arce, N.D., Schepper, J.D., Parameswaran, N. \& McCabe, L.R. The Potential 8 of Probiotics as a Therapy for Osteoporosis. Microbiol Spectr 5(2017).

9 18. Grover, S., Del, G.M.F., Stein, C.M. \& Ziegler, A. Mendelian Randomization. Methods Mol Biol 10 1666, 581-628 (2017).

19. Kurt, R. \& Smolen, J.S. Inflammatory bone loss: pathogenesis and therapeutic intervention. NAT REV DRUG DISCOV 11, 234-250 (2012).

20. Giridharan, S. \& Srinivasan, M. Mechanisms of NF-kappaB p65 and strategies for therapeutic manipulation. J Inflamm Res 11, 407-419 (2018).

21. Couper, K.N., Blount, D.G. \& Riley, E.M. IL-10: the master regulator of immunity to infection. $J$ IMMUNOL 180, 5771-5777 (2008). 15, 682-689 (2009).

23. Nobel, Y.R., et al.. Metabolic and metagenomic outcomes from early-life pulsed antibiotic treatment. NAT COMMUN 6, 7486 (2015).

24. Larsen, O.F.A. \& Claassen, E. The mechanistic link between health and gut microbiota diversity. Sci Rep 8(2018).

25. Sprent, P. Sign Test, (2011).

26. Koller, D.L., et al.. Meta-analysis of genome-wide studies identifies WNT16 and ESR1 SNPs associated with bone mineral density in premenopausal women. $J$ BONE MINER RES 28, 547-558 (2013).

27. Cuív, P.Ó., et al.. The gut bacterium and pathobiont Bacteroides vulgatus activates NF- $\kappa$ B in a human gut epithelial cell line in a strain and growth phase dependent manner. ANAEROBE 47, 209-217 (2017). 
medRxiv preprint doi: https://doi.org/10.1101/2020.03.16.20037077; this version posted March 27, 2020. The copyright holder for this preprint (which was not certified by peer review) is the author/funder, who has granted medRxiv a license to display the preprint in It is made available under a CC-BY-NC-ND 4.0 International license .

1 activation by gentian violet promotes osteoblastogenesis and suppresses osteoclastogenesis. CURR

2 MOL MED 14, 783-792 (2014).

29. Bhanu Chandra, M., Salmaan, K., Alex, L. \& Wei-Shou, H. Glucose metabolism in mammalian cell culture: new insights for tweaking vintage pathways. TRENDS BIOTECHNOL 28, 476-484 (2010). 30. Boffi, F.M., et al.. Effects of chemical ischemia on purine nucleotides, free radical generation, lipids peroxidation and intracellular calcium levels in $\mathrm{C} 2 \mathrm{C} 12$ myotube derived from mouse myocytes. $J$ VET MED SCI 64, 483 (2002).

31. Moriarty, D.J.W. Measurement of Bacterial Growth Rates in Aquatic Systems from Rates of Nucleic Acid Synthesis, (1986).

32. Rooks, M.G. \& Garrett, W.S. Gut microbiota, metabolites and host immunity. NAT REV IMMUNOL 16, 341-352 (2016).

33. Yan, J., et al.. Gut microbiota induce IGF-1 and promote bone formation and growth. Proc Natl Acad Sci U S A 113, E7554-E7563 (2016).

34. Park, J.S., Lee, E.J., Lee, J.C., Kim, W.K. \& Kim, H.S. Anti-inflammatory effects of short chain fatty acids in IFN- $\gamma$-stimulated RAW 264.7 murine macrophage cells: Involvement of NF- $\kappa$ B and ERK signaling pathways. INT IMMUNOPHARMACOL 7, 70-77 (2007).

35. Heyen, J.R., Ye, S., Finck, B.N. \& Johnson, R.W. Interleukin (IL)-10 inhibits IL-6 production in microglia by preventing activation of NF-kappaB. Brain Res Mol Brain Res 77, 138-147 (2000).

36. Yuille, S., Reichardt, N. \& Panda, S. Human gut bacteria as potent class I histone deacetylase inhibitors in vitro through production of butyric acid and valeric acid. PLOS ONE 13, e201073 (2018). 37. Li, Y., et al.. Gut commensal derived-valeric acid protects against radiation injuries. Gut Microbes, 1-18 (2020).

38. Sandra, M. \& Macfarlane, G.T. Regulation of short-chain fatty acid production. P NUTR SOC 62, 67-72 (2003).

39. Coyte, K.Z. \& Rakoff-Nahoum, S. Understanding Competition and Cooperation within the Mammalian Gut Microbiome. CURR BIOL 29, R538-R544 (2019).

40. Buchfink, B., Xie, C. \& Huson, D.H. Fast and sensitive protein alignment using DIAMOND. NAT METHODS 12, 59-60 (2015).

41. Huson, D., Auch, A.J. \& Schuster, S. MEGAN analysis of metagenomic data. GENOME RES 17, 377-386 (2007). 
medRxiv preprint doi: https://doi.org/10.1101/2020.03.16.20037077; this version posted March 27, 2020. The copyright holder for this preprint (which was not certified by peer review) is the author/funder, who has granted medRxiv a license to display the preprint in It is made available under a CC-BY-NC-ND 4.0 International license .

1 42. Jain, M., et al.. The importance of rare species: a trait-based assessment of rare species 2 contributions to functional diversity and possible ecosystem function in tall-grass prairies. ECOL 3 EVOL 4, 104-112(2014).

4 43. Piercy, K.L. \& Troiano, R.P. Physical Activity Guidelines for Americans From the US 5 Department of Health and Human Services. Circ Cardiovasc Qual Outcomes 11, e5263 (2018).

6 44. Du, Y., Zhao, L.J., Xu, Q., Wu, K.H. \& Deng, H.W. Socioeconomic status and bone mineral 7 density in adults by race/ethnicity and gender: the Louisiana osteoporosis study. Osteoporos Int 28, $8 \quad 1699-1709$ (2017).

9 45. Zhou, S., et al.. Age-dependent variations of cancellous bone in response to ovariectomy in 10 C57BL/6J mice. EXP THER MED 15, 3623-3632 (2018).

46. Magnus, M.C et al. Vitamin D and risk of pregnancy related hypertensive disorders: mendelian 12 randomisation study. $B M J \mathbf{3 6 1}$, - (2018).

47. Sanna, S., et al.. Causal relationships among the gut microbiome, short-chain fatty acids and metabolic diseases. NAT GENET 51, 600-605 (2019). 48. Sudmant, P.H., et al.. An integrated map of structural variation in 2,504 human genomes. NATURE 526, 75-81 (2015). Randomization with Some Invalid Instruments Using a Weighted Median Estimator. GENET EPIDEMIOL 40, 304-314 (2016).

50. Schmittgen, T.D. \& Livak, K.J. Analyzing real-time PCR data by the comparative C(T) method. 
medRxiv preprint doi: https://doi.org/10.1101/2020.03.16.20037077; this version posted March 27, 2020. The copyright holder for this preprint (which was not certified by peer review) is the author/funder, who has granted medRxiv a license to display the preprint in It is made available under a CC-BY-NC-ND 4.0 International license

\section{Acknowledgement}

2 HW Deng and H Shen were partially supported by grants from the National Institutes

3 of Health [U19AG05537301, R01AR069055, P20GM109036, R01MH104680,

4 R01AG061917], and the Edward G. Schlieder Endowment and the Drs. W. C. Tsai

5 and P. T. Kung Professorship from Tulane University. J Shen was partially supported

6 by grants from the Science and Technology Program of Guangzhou, China

7 [201604020007], and the National Natural Science Foundation of China [81770878].

8 HM Xiao was partially supported by the National Key R\&D Program of China 9 (2016YFC1201805 and 2017YFC1001100).

We thank Feng-Zhu Sun, Guo-Zhen Wang, Jun Wang, Wei-Chang Huang, Zun Wang,

11 Yong Liu, Lin-Dong Jiang, Rui-Ke Liu, Zhi-Mei Feng, Yuan-Yuan Hu, Lin-Ping Peng and Chun-Ping Zeng for their suggestions and supports for this study.

\section{Author contributions}

HWD conceived, designed, initiated and directed the whole project. JG, QZ, KJS, XHM, FYL, and CLG contributed to the data analysis. JS and HMX managed the study done in their institutions. DYP, ZC, and ZFL performed clinical diagnosis and recruited subjects. CP, XJX, YCC, RZ, XFW, ZXA, JML, YQS, and YHZ collected samples and clinical phenotypes. SJY conducted animal experiments. XL drafted the manuscript. HWD revised, rewrote/re-structured some sections and finalized the manuscript. NJY, QZ, BYG, HML, WQL, CJP, XMS and HS contributed to text revision and/or discussion. 
medRxiv preprint doi: https://doi.org/10.1101/2020.03.16.20037077; this version posted March 27, 2020. The copyright holder for this preprint (which was not certified by peer review) is the author/funder, who has granted medRxiv a license to display the preprint in It is made available under a CC-BY-NC-ND 4.0 International license .

1

2 Author information

3 The authors declare no competing financial interests.

4 Correspondence and requests for materials should be addressed to Hong-Wen Deng

5 (hdeng2@tulane.edu), Jie Shen (shenjiedr@163.com) and Hong-Mei Xiao

6 (hmxiao@csu.edu.cn).

7 The data that support the findings of this study are available from the corresponding

8 author upon request and approval of the team and respective institutions.

9 
medRxiv preprint doi: https://doi.org/10.1101/2020.03.16.20037077; this version posted March 27, 2020. The copyright holder for this preprint (which was not certified by peer review) is the author/funder, who has granted medRxiv a license to display the preprint in It is made available under a CC-BY-NC-ND 4.0 International license

1 Table 1. Characteristics of the Chinese study cohort

\begin{tabular}{ccccc}
\hline Phenotypes & Max & Min & Mean & Standard Deviation \\
\hline Age (years) & 64.59 & 41.47 & 52.85 & 2.92 \\
BMI $\left(\mathrm{kg} / \mathrm{m}^{2}\right)$ & 33.73 & 16.42 & 22.97 & 2.87 \\
YSM (years) & 8.99 & 0.06 & 1.96 & 0.94 \\
FSH $(\mathrm{mIU} / \mathrm{mL})$ & 208.20 & 1.08 & 76.24 & 32.63 \\
L1-L4 BMD $\left(\mathrm{g} / \mathrm{cm}^{2}\right)$ & 1.85 & 0.69 & 1.05 & 0.16 \\
HTOT BMD $\left(\mathrm{g} / \mathrm{cm}^{2}\right)$ & 1.36 & 0.61 & 0.93 & 0.12 \\
FN BMD $\left(\mathrm{g} / \mathrm{cm}^{2}\right)$ & 1.26 & 0.58 & 0.86 & 0.12 \\
UD-RU BMD $\left(\mathrm{g} / \mathrm{cm}^{2}\right)$ & 0.61 & 0.22 & 0.40 & 0.06 \\
\hline
\end{tabular}

2 Abbreviations:

3 YSM - years since menopause; FSH - follicle stimulating hormone; BMI - body mass

4 index; BMD - bone mineral density; L1-L4 - lumbar spine; HTOT - left total hip; FN

5 - femoral neck; UD-RU - ultra-distal radius and ulna. 
medRxiv preprint doi: https://doi.org/10.1101/2020.03.16.20037077; this version posted March 27, 2020. The copyright holder for this preprint (which was not certified by peer review) is the author/funder, who has granted medRxiv a license to display the preprint in It is made available under a CC-BY-NC-ND 4.0 International license.

1 Table 2. Correlation between GM functional capacity and BMD variation

\begin{tabular}{cccccc}
\hline $\begin{array}{c}\text { Module } \\
\text { ID }\end{array}$ & $\boldsymbol{\gamma}$ & $\boldsymbol{p}$-value & $\boldsymbol{Q}$-value & Module names & Phenotypes \\
\hline M00002 & -0.122 & 0.007 & 0.234 & Glycolysis & L1-L4 BMD \\
M00048 & -0.119 & 0.008 & 0.234 & IMP biosynthesis & L1-L4 BMD \\
M00855 & -0.119 & 0.008 & 0.234 & Glycogen degradation & L1-L4 BMD \\
M00002 & -0.118 & 0.009 & 0.153 & Glycolysis & UD-RU BMD \\
M00003 & -0.119 & 0.008 & 0.153 & Gluconeogenesis & UD-RU BMD \\
M00050 & -0.143 & 0.002 & 0.079 & GTP biosynthesis & UD-RU BMD \\
M00727 & -0.135 & 0.003 & 0.079 & CAMP resistance & UD-RU BMD \\
\hline
\end{tabular}

2 Note:

$3 \gamma$ - coefficient of the partial Spearman correlation between GM functional module and 4 phenotype; $p$-value - $p$-value of the coefficient in partial Spearman correlation 5 analysis; $Q$-value - $p$-value adjusted by false discovery rate; Glycolysis 6 core module involving three-carbon compounds; IMP biosynthesis 7 - PRPP + glutamine $\rightarrow$ IMP; Glycogen degradation - glycogen $\rightarrow$ glucose-6P; 8 Gluconeogenesis - oxaloacetate $\rightarrow$ fructose-6P; GTP biosynthesis - IMP $\rightarrow$ GDP, 9 GTP; CAMP resistance - N-acetylmuramoyl-L-alanine amidase AmiA and AmiC. We 10 only tested the modules whose relative abundance $>0.10 \%$.

11 Abbreviations:

12 GM - gut microbiota; BMD - bone mineral density; L1-L4 - lumbar spine; UD-RU 13 ultra-distal radius and ulna; PRPP - phosphoribosylpyrophosphate; IMP - inosine 14 monophosphate; GDP - guanosine 5'-diphosphate; GTP - guanosine 5'-triphosphate; 15 CAMP - cationic antimicrobial peptide. 
medRxiv preprint doi: https://doi.org/10.1101/2020.03.16.20037077; this version posted March 27, 2020. The copyright holder for this preprint (which was not certified by peer review) is the author/funder, who has granted medRxiv a license to display the preprint in It is made available under a CC-BY-NC-ND 4.0 International license .

$1 \quad$ Figure legends

2 Figure 1. Unigene accumulation curve, bacterial species composition and 3 correlation 
(a)

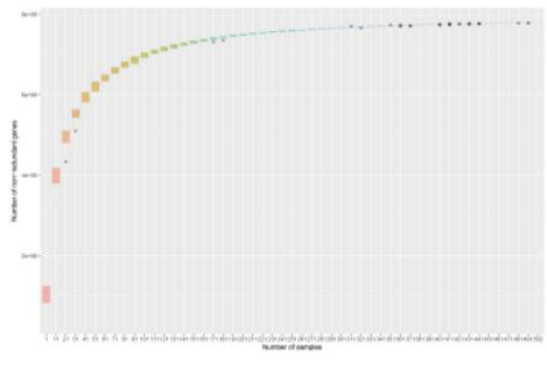

(b)

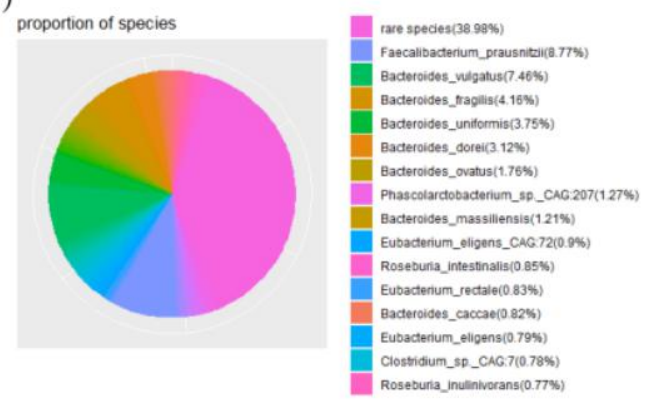

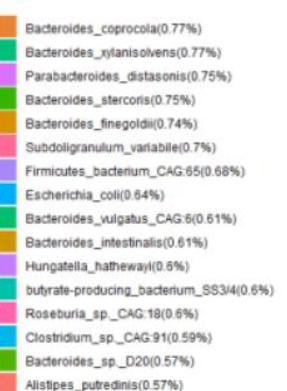

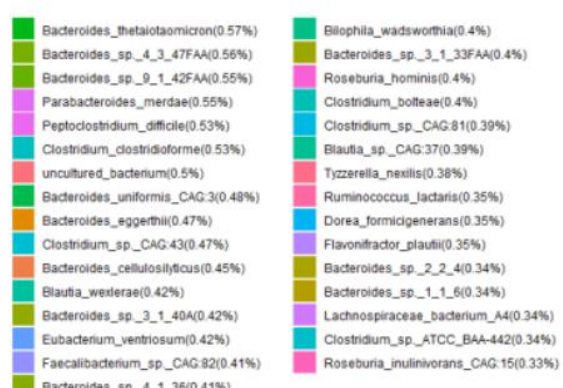

(c)

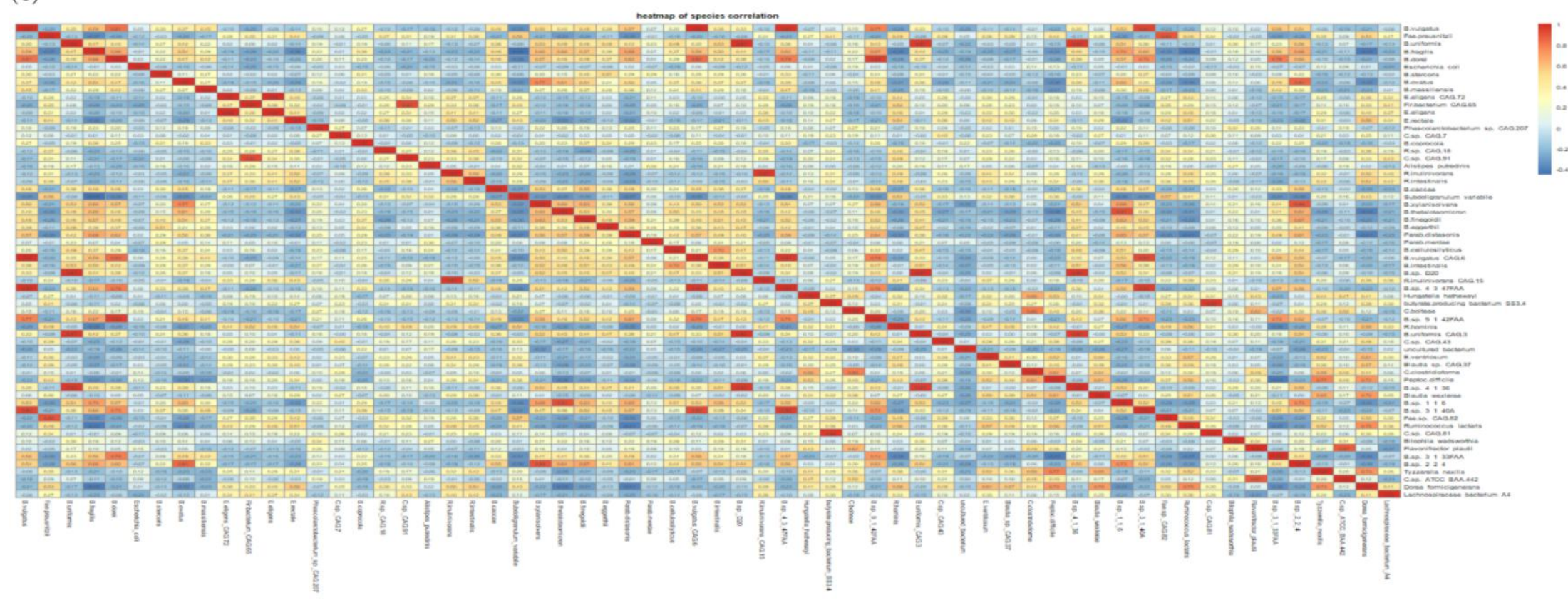


(a) Unigene accumulation curve: the number of unigenes (y-axis) was plotted against the number of samples (x-axis). (b) Bacterial species composition in the study cohort composed of rare and non-rare bacterial species. Different colours represent different bacterial species. Numbers in parentheses indicate the proportion of each bacterial species. "Rare species" include all those bacterial species with relative abundances less than $0.10 \%$. (c) Heatmap of co-occurrence between the relative abundances of non-rare species. Numbers in the plot 5 represent Spearman correlation coefficients of pairwise two bacterial species. 
medRxiv preprint doi: https://doi.org/10.1101/2020.03.16.20037077; this version posted March 27, 2020. The copyright holder for this preprint (which was not certified by peer review) is the author/funder, who has granted medRxiv a license to display the preprint in It is made available under a CC-BY-NC-ND 4.0 International license.

Figure 2. Bacteroides vulgatus regulates bone remodeling in mice in vivo

Figure 2

(a)

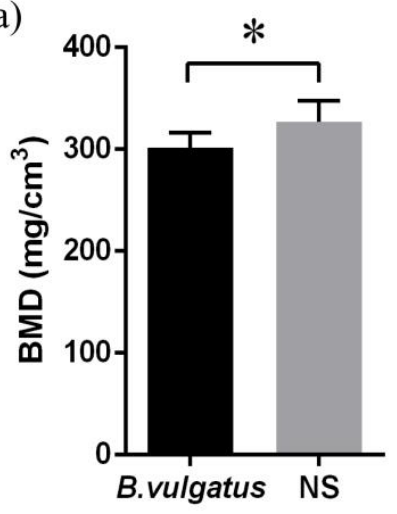

(d)
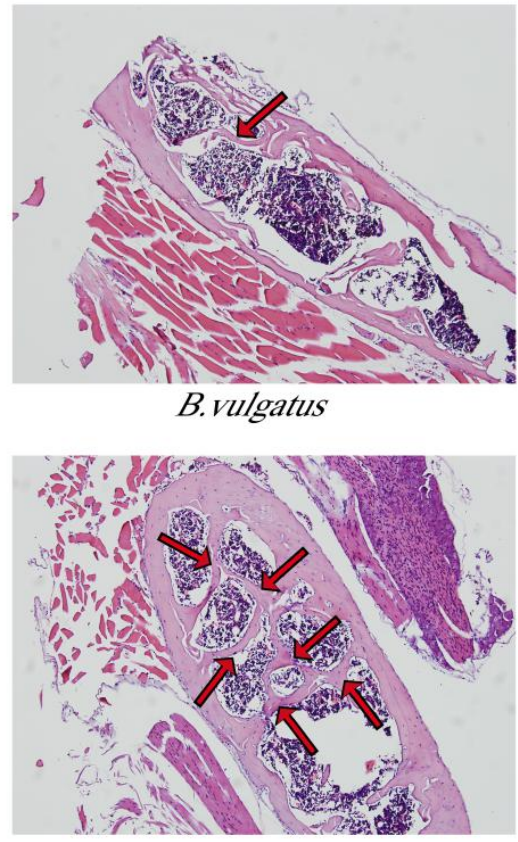

NS (b)

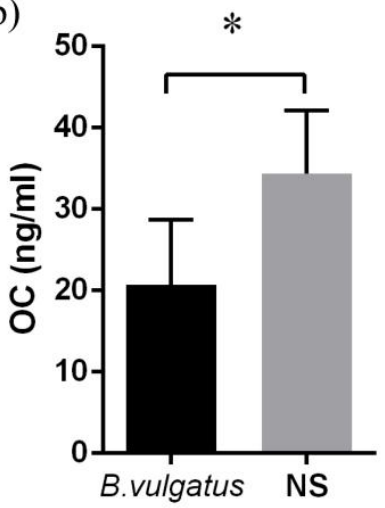

(e)

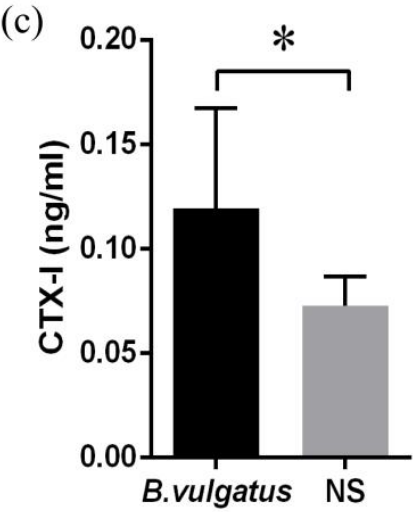

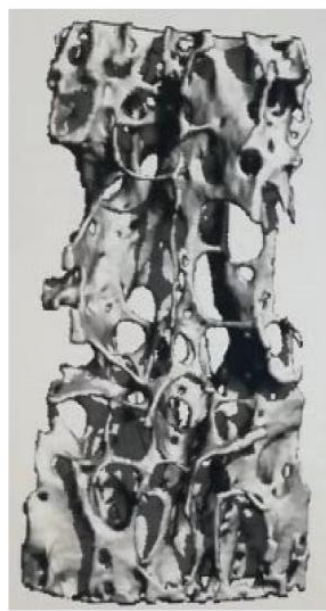

B. vulgatus

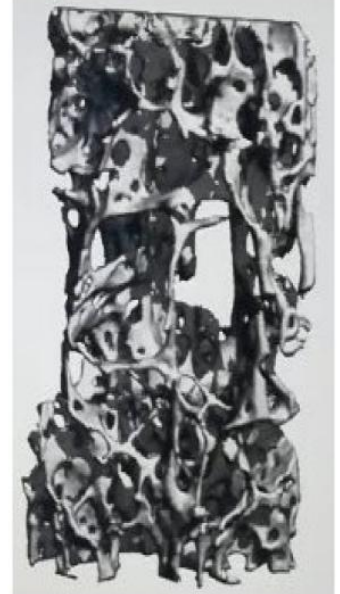

NS

Changes in various bone-associated phenotypes in mice gavaged with B. vulgatus or normal saline (NS) for 8 weeks (performed at age of 8 weeks after ovariectomy): (a) bone mineral density (BMD) of the $5^{\text {th }}$ lumbar vertebral body; (b) serum osteocalcin (OC) concentrations; (c) serum C-telopeptide of type I collagen (CTX-I) concentrations; (d) representative histomorphology of the $5^{\text {th }}$ lumbar vertebral body using hematoxylin-eosin staining. Red arrows point to trabecular bone; (e) representative micro-computed tomograph images of the $5^{\text {th }}$ lumbar vertebral body by three-dimensional reconstructions. (Note: in $\mathrm{A}, \mathrm{B}$, and $\mathrm{C}, \mathrm{n}=18$, and $*$ indicates $p$-value $<0.05$. 
medRxiv preprint doi: https://doi.org/10.1101/2020.03.16.20037077; this version posted March 27, 2020. The copyright holder for this preprint (which was not certified by peer review) is the author/funder, who has granted medRxiv a license to display the preprint in It is made available under a CC-BY-NC-ND 4.0 International license .

\section{Figure 3. Valeric acid influences osteoclast and osteoblast differentiation in vitro} Figure 3

(a)
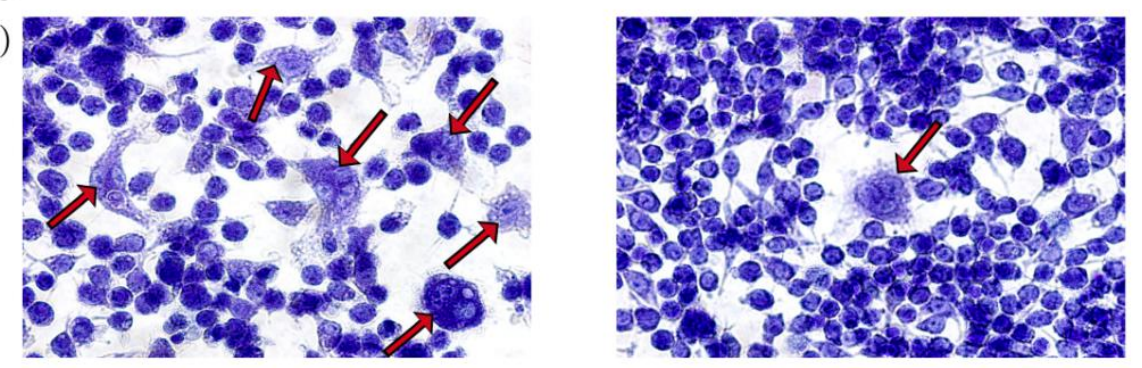

RANKL

RANKL + VA

(b)

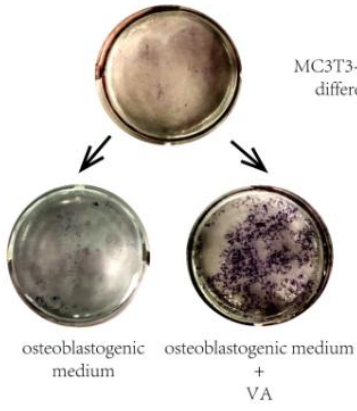

ALP

MC3T3-E1 without
differentiation
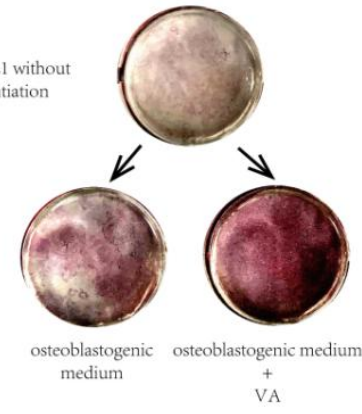

AR-S

(c) $\mathrm{NF}-\kappa \mathrm{B}$ p65
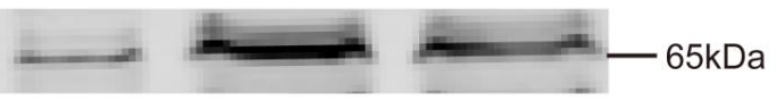

GAPDH

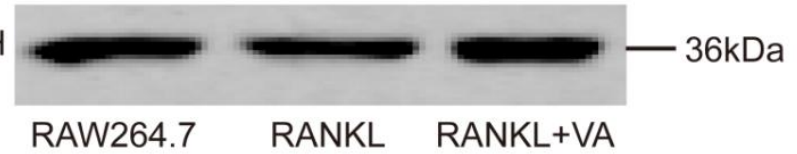

RAW264.7

RANKL RANKL+VA

(d) $N F-\kappa B$ p65
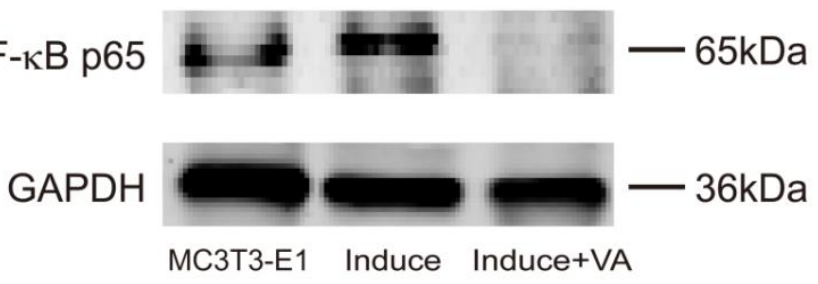

(f)
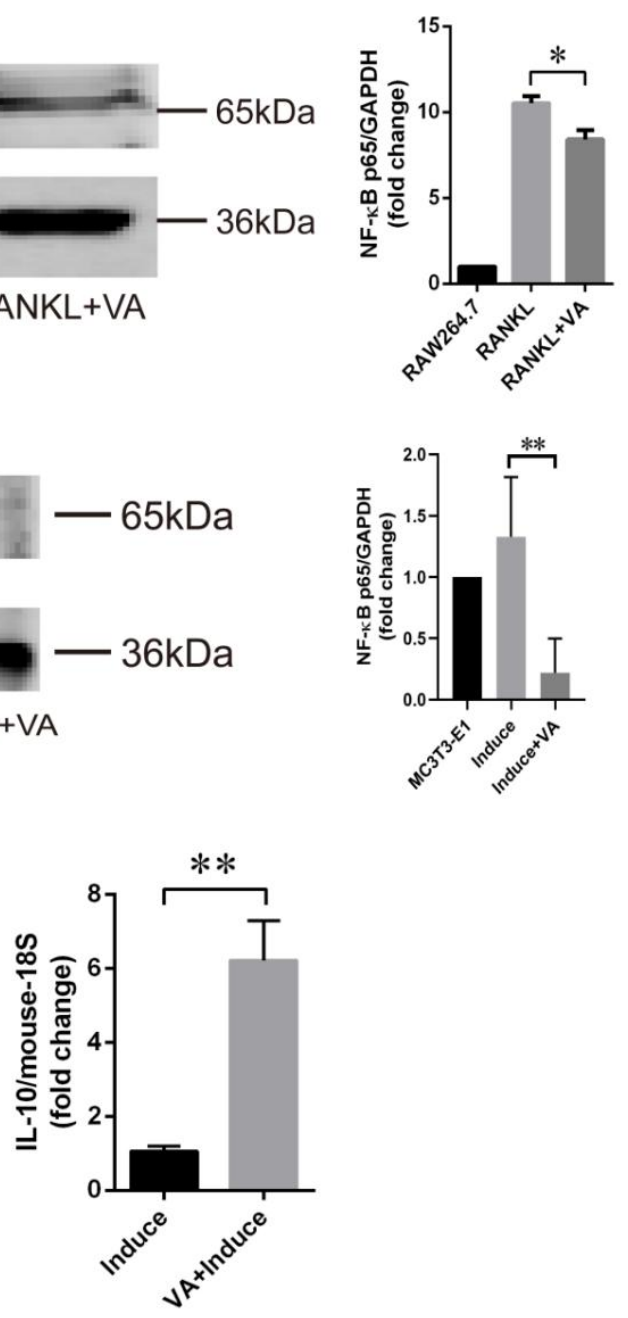

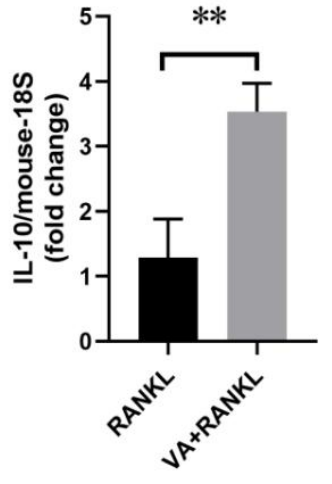

(e) 
medRxiv preprint doi: https://doi.org/10.1101/2020.03.16.20037077; this version posted March 27, 2020. The copyright holder for this preprint (which was not certified by peer review) is the author/funder, who has granted medRxiv a license to display the preprint in It is made available under a CC-BY-NC-ND 4.0 International license .

1 Effects of valeric acid (VA) on osteoclast differentiation of RAW264.7 cells (induced 2 by receptor activator of nuclear factor- $\kappa \mathrm{B}$ ligand [RANKL]) and osteoblast 3 differentiation of MC3T3-E1 cells: (a) Microscopic images of tartrate-resistant acid 4 phosphatase staining of osteoclast-like cells induced from RAW264.7 cells after 5 5 days of osteoclastogenesis with/without VA treatment. Red arrows indicate 6 osteoclast-like cells. (b) Alkaline phosphatase (ALP) staining for osteoblast 7 differentiation and alizarin red $\mathrm{S}$ (AR-S) staining for extracellular matrix 8 mineralization by MC3T3-E1 cells after 14 days of osteoblastogenesis with/without 9 VA treatment; (c) Western blot of NF- $\mathrm{BB}$ p65 protein in osteoclast-like cells

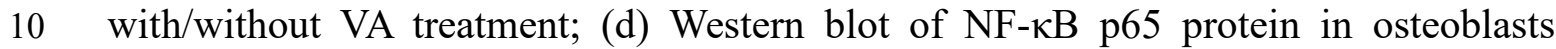
11 with/without VA treatment; the "induce" means the MC3T3-E1 cells were induced 12 into osteoblasts by osteoblastogenic medium without VA; (e) IL-10 mRNA expression 13 in osteoclast-like cells with/without VA; (f) IL-10 mRNA expression in osteoblasts 14 with/without VA. $*$ indicates $p$-value $<0.05$, and $* *$ means $p$-value $<0.01$. 